\title{
PENGARUH RETURN ON EQUITY (ROE) DAN CURRENT RATIO (CR) TERHADAP HARGA SAHAM
}

\author{
Sesilia Meilani 1 \\ Irvan Yoga Pardistya 2
}

\author{
Fakultas Ekonomi Universitas Singaperbangsa Karawang, Jawa Barat,Indonesia ${ }^{1,2}$ \\ Email: sesilia.meilani@gmail.com¹ irvan.yoga@fe.unsika.ac.id ${ }^{2}$
}

\begin{abstract}
Property and real estate companies are businesses that have an important role in national economic growth because investments in this field are generally long-term. This field is also one of the promising investments because land and building prices tend to increase every year. Investment through stock prices is a factor that needs to be considered by investors who will invest in companies in this field. To overcome the changes in stock prices every day even every second. So investors must be able to pay attention to the factors that affect stock prices. This study uses independent variables are Return On Equity and Current Ratio and the dependent variable is the stock price. The research sample selected by purposive sampling in the property and real estate company annual reporting period is 2015-2019. Research methods with quantitative methods through descriptive and verification approaches. The analysis tool is SPSS version 25. The results of the research show that there is a significant influence between the return on equity and the stock price, while the current ratio to the stock price has no significant effect. Simultaneously there is a significant effect between return on equity and current ratio on stock prices.
\end{abstract}

Keywords:ROE; CR; Stock Price.

\begin{abstract}
ABSTRAK
Perusahaan property dan real estate merupakan bisnis yang memiliki peranan penting dalam pertumbuhan perekonomian nasional karena investasi di bidang ini umumnya bersifat jangka panjang. Bidang ini juga menjadi salah satu investasi yang menjanjikan karena harga tanah dan bangunan dari tahun ke tahun selalu cenderung meningkat setiap tahun. Investasi melalui harga saham menjadi faktor yang perlu diperhatikan oleh investor yang akan melakukan investasi pada perusahaan dibidang ini. Untuk mengatasi adanya perubahan terhadap harga saham setiap harinya bahkan setiap detik. Sehingga investor harus mampu memperhatikan faktor-faktor yang mempengaruhi harga saham. Penelitian ini menggunakan variabel independen adalah Return On Equity dan Current Ratio dan variabel dependen adalah harga saham. Sampel penelitian yang dipilih dengan purposive sampling pada perusahaan property dan real estate periode laporan tahunan yaitu 2015-2019. Metode penelitian dengan metode kuantitatif melalui pendekatan deskriptif dan verifikatif. Alat analisis adalah SPSS versi 25. Hasil penelitian menunjukkan secara parsial terdapat pengaruh secara signifikan antara return on equity terhadap harga saham, sedangkan current ratio terhadap harga saham tidak terdapat pengaruh secara signifikan. Secara simultan terdapat pengaruh signifikan antara return on equity dan current ratio terhadap harga saham.
\end{abstract}

Kata kunci: ROE; CR; Harga Saham. 


\section{PENDAHULUAN}

Perkembangan investasi di indonesia meningkat setiap tahunnya. Saat ini investasi menjadi faktor yang paling penting dalam pertumbuhan ekonomi suatu negara. Terdapat banyak instrumen investasi dari berbagai macam perusahaan yang dapat dipilih di pasar modal, maka kesempatan investasi juga lebih menjanjikan. Adanya pasar modal juga dapat membantu perusahaan yang membutuhkan modal untuk memenuhi kelangsungan hidup perusahaan. Seorang Investor melakukan investasinya dapat berupa deposito, obligasi maupun saham. Instrumen yang sering digunakan untuk berinvestasi pada pasar modal adalah saham (Imelda et al., 2018).

Harga saham menjadi faktor yang perlu diperhatikan oleh investor yang akan melakukan investasi. Investasi dengan perusahaan property dan real estate merupakan bisnis yang memiliki peranan penting dalam pertumbuhan perekonomian nasional karena investasi di bidang properti dan real estate umumnya bersifat jangka panjang dan akan bertumbuh sejalan dengan pertumbuhan ekonomi. Bidang ini juga menjadi salah satu investasi yang menjanjikan karena dalam kenyataannya harga tanah dan bangunan dari tahun ke tahun selalu cenderung meningkat setiap tahun.

Hal ini dapat dilihat dari faktor persediaan akan tanah sifatnya tetap sedangkan permintaan akan selalu bertambah. Faktor lain adalah bertambahnya jumlah penduduk setiap tahunnya serta kebutuhan manusia yang akan selalu bertambahnya seperti tempat tinggal, perkantoran, pusat perbelanjaan, taman 
hiburan dan lain-lain. Sudah selayaknya perusahaan yang mengalami perkembangan mendapatkan keuntungan yang besar dari kenaikan harga properti tersebut. Keuntungan yang diperoleh tersebut akan memperbaiki perusahaan pengembang mengenai kinerja keuangannya sehingga dapat mendongkrak harga saham. Hal ini yang membuat peneliti tertarik untuk menjadikan perusahaan property dan real estate sebagai objek yang akan diteliti.

Tingkat perkembangan harga saham akan menjadi acuan dalam menilai perusahaan yang terdapat di pasar modal. Tingginya harga saham suatu perusahaan, menandakan semakin tinggi juga nilai perusahaan tersebut. Maka hal ini akan menambah minat para investor untuk menginvestasikan modalnya dan membeli saham pada perusahaan tersebut (Manoppo et al., 2017). Investasi yang diharapkan dapat memberikan keuntungan bagi investor di masa depan. Hasil dari keuntungan tersebut dapat digunakan sebagai sumber dana yang dapat diolah kembali bagi investor untuk memenuhi keperluan yang dibutuh oleh investor. Untuk mengatasi adanya perubahan terhadap harga saham setiap harinya bahkan setiap detik. Oleh karena itu, investor harus mampu memperhatikan faktor-faktor yang mempengaruhi harga saham.

Informasi-informasi akurat yang berhubungan dengan saham sangat dibutuhkan oleh para investor yang ingin berinvestasi dalam bentuk saham sebagai bahan pertimbangan dalam menentukan pilihan. Investor dalam menentukan pilihannya perlu mengetahui kondisi keuangan perusahaan yang dapat dilihat dari laporan keuangan perusahaan yang terdapat di laporan tahunan 
perusahaan yang dilaporkan dalam bursa efek Indonesia. Analisis laporan keuangan bermanfaat baik untuk membantu mengantisipasi kondisi-kondisi dimasa depan, dapat digunakan oleh investor dalam menentukan pengambilan keputusan investasi seperti menjual dan membeli saham, maupun sebagai titik awal untuk melakukan perencanaan langkah-langkah yang akan meningkatkan kinerja perusahaan dimasa mendatang, (Manoppo et al., 2017).

Dalam penelitian ini penulis memaparkan rasio keuangan yang digunakan untuk memprediksi harga saham oleh investor dengan menggunakan return on equity sebagai rasio profitabilitas. Return on Equity (ROE) adalah rasio untuk mengukur laba bersih sesudah pajak dengan modal sendiri (Kasmir 2012). Kegunaan dari Return on Equity (ROE) untuk mengukur kemampuan dari modal sendiri dalam menghasilkan keuntungan bagi seluruh pemegang saham, bagi saham biasa maupun saham preferen.

Nilai ROE yang tinggi, tentunya akan menarik minat para investor untuk menanamkan modalnya pada perusahaan bersangkutan karena menandakan bahwa perusahaan tersebut memiliki kinerja yang baik sehingga harga saham pun akan ikut tinggi (Rahmadewi \& Abundanti, 2018). Semakin tinggi rasio ini maka semakin efisien penggunaan modal sendiri yang dilakukan oleh pihak manajemen perusahaan. Apabila laba yang dihasilkan semakin banyak maka investor memperoleh keuntungan yang semakin besar atas investasi yang dilakukannya. Semakin besar rasio ini maka menunjukkan semakin efisien perusahaan dalam mengelola modal sendiri yang dimiliki perusahaan (Sudana, 2011). 
Penelitian tentang pengaruh return on equity terhadap harga saham pernah dilakukan oleh Rianisari et al., (2018) menyatakan bahwa ROE berpengaruh positif dan signifikan terhadap harga saham. Hal yang sama juga dinyatakan oleh Pratama et al., (2019) menyatakan bahwa "Pengujian secara parsial dalam penelitiannya menunjukkan bahwa variabel Return On Equity (ROE) mempunyai pengaruh signifikan terhadap harga saham". Namun tidak didukung oleh Munira et al., (2018) menyatakan bahwa "ROE secara parsial tidak memiliki pengaruh yang berarti terhadap harga saham".

Rasio keuangan lain yang digunakan dalam penelitian ini dengan Current Ratio (CR) merupakan ukuran yang paling umum digunakan untuk mengetahui kesanggupan memenuhi kewajiban jangka pendek. Apabila terjadi penurunan harga pasar dari harga saham maka akan mempengaruhi current ratio yang bersangkutan menjadi rendah. Sebaliknya current ratio terlalu tinggi juga belum tentu baik, karena pada kondisi tertentu hal tersebut mengindikasi bahwa banyak dana perusahaan yang menganggur yang akhirnya dapat mengurangi keuntungan perusahaan, (Rahmadewi \& Abundanti, 2018).

Rasio ini dapat dijadikan sebagai dasar perhitungan dari likuiditas jangka pendek yang paling utama karena melingkupi seluruh bagian aktiva lancar dan seluruh bagian hutang lancar tanpa membedakan tingkatan dari likuiditasnya. Apabila aktiva lancarnya melebihi hutang lancarnya, maka dapat diprediksikan bahwa pada suatu ketika dilakukan likuiditas, aktiva lancar memiliki cukup kas ataupun yang mudah diubah menjadi uang kas dalam jangka waktu singkat, 
sehingga dapat memenuhi kewajibannya, (Amanah et al., 2014).

Penelitian tentang pengaruh current ratio terhadap harga saham pernah dilakukan oleh Imelda et al., (2018) current ratio mempunyai pengaruh signifikan terhadap harga saham. Namun tidak didukung oleh Efrizon, (2017) menyatakan bahwa current ratio tidak mempunyai pengaruh yang signifikan terhadap harga saham. Hal sama dinyatakan oleh Pratama et al., (2019) menurut penelitian yang mereka lakukan tidak berpengaruh secara signifikan antara current ratio terhadap harga saham.

Berdasarkan latar belakang tersebut dan berdasarkan hasil penelitian terdahulu serta untuk mengetahui informasi manakah yang lebih mempengaruhi dan tidak mempengaruhi. Maka penulis tertarik meneliti lebih lanjut dengan judul "Pengaruh Return On Equity (ROE) dan Current Ratio (CR) terhadap Harga Saham pada Perusahaan Subsektor Property Dan Real Estate yang Terdaftar di Bursa Efek Indonesia Periode 2015-2019”.

\section{METODE PENELITIAN}

Metode penelitian yang digunakan adalah metode kuantitatif pendekatan deskriptif dan verifikatif. Adapun populasi dalam penelitian ini adalah perusahaan subsektor property dan real estate yang terdaftar di Bursa Efek Indonesia periode 2015-2019 dengan cara mengakses halaman www.idx.co.id. Halaman ini digunakan untuk mendapatkan informasi yang diungkapkan dalam laporan keuangan dan laporan tahunan periode 2015-2019 dalam memperoleh nilai return on equity dan current ratio. Harga saham diperoleh dari Indonesian Capital 
Market Directory (ICMD) dan finance yahoo melalui website https://finance.yahoo.com/. Pengambilan sampel menggunakan metode purposive sampling. Metode pemilihan sampel dengan purposive sampling menurut Rochaety et al., (2019:55) adalah teknik penentuan sampel dengan pertimbangan tertentu yang disesuaikan dengan tujuan dan masalah penelitian. Sehingga diperoleh 13 perusahaan yang menjadi sampel dalam penelitian ini.

Adapun pertimbangan yang ditetapkan dalam pengambilan sampel pada penelitian ini ditentukan sebagai berikut: Perusahaan property dan real estate yang terdaftar di BEI periode 2015-2019, Perusahaan property dan real estate yang menerbitkan laporan tahunan secara tidak lengkap dan berturut-turut pada tahun 2015-2019, Perusahaan property dan real estate dengan data yang tidak lengkap terkait dengan variabel-variabel penelitian, Perusahaan property dan real estate yang mengalami kerugian selama periode 2015-2019.

Teknik analisis data menggunakan regresi linier berganda yang merupakan salah satu teknik statistika yang dapat digunakan untuk menggambarkan hubungan antara dua atau lebih variabel penelitian. Model persamaan regresi adalah sebuah formula yang menggambarkan hubungan antar variabel penelitian. Persamaan regresi dapat digunakan untuk meramalkan nilai suatu variabel. Model persamaannya adalah sebagai berikut :

$$
\mathrm{Y}=\alpha+\beta_{1} X_{1}+\beta_{2} X_{2}+e
$$

Keterangan :

$\mathrm{Y}$

$\mathrm{X}_{1}$

$\mathrm{X}_{2}$
: Harga Saham

: Return On Equity

: Current Ratio 


$$
\begin{array}{ll}
\alpha & : \text { Konstanta } \\
\mathrm{B}_{1}, \beta_{2} & : \text { Koefisien Regresi } \\
\mathrm{e} & : \text { Faktor Penggangu Diluar Model }
\end{array}
$$

\section{HASIL DAN PEMBAHASAN}

Analisis statistik deskriptif digunakan untuk memberikan gambar mengenai masing-masing variabel penelitian. Berdasarkan tabel 1 menunjukan variabel independen yaitu Return On Equity (ROE) dapat diketahui nilai minimum sebesar -0,06 dan nilai maximum sebesar 3,46. Nilai mean pada Return On Equity (ROE) sebesar 2,1162. Nilai standar deviasi pada Return On Equity (ROE) sebesar 0,75151.

Analisis statistik deskriptif dari penelitian ini menunjukkan hasil sebagai berikut ini:

\section{Tabel 1.}

Hasil Analisis Statistic Deskriptif

\begin{tabular}{lccccc}
\hline Variabel & N & Minimum & Maximum & Mean & $\begin{array}{c}\text { Std. } \\
\text { Deviation }\end{array}$ \\
\hline ROE & 53 & $-0,06$ & 3,46 & 2,1162 & 0,75151 \\
CR & 53 & 4,17 & 7,04 & 5,1616 & 0,67828 \\
Harga Saham & 53 & 4,06 & 8,49 & 5,9955 & 0,98681 \\
\hline
\end{tabular}

Sumber: Data diolah peneliti, 2020

Pada variabel independen yaitu Current Ratio (CR) dapat diketahui nilai minimum sebesar 4,17 dan nilai maximum sebesar 7,04. Pada Current Ratio (CR) dengan nilai mean sebesar 5,1616. Nilai standar deviasi Current Ratio (CR) sebesar 0,67828. Pada variabel dependen yaitu harga saham dapat diketahui nilai minimum sebesar 4,06 dan nilai maximum sebesar 8,49 . Pada harga saham nilai 
mean sebesar 5,9955.

Nilai minimum dan maximum digunakan untuk mengetahui teknik penjelasan kelompok yang didasarkan atas jumlah terkecil dan terbesar dari data kelompok yang bersangkutan. Mean digunakan untuk mengetahui teknik penjelasan kelompok yang didasarkan atas rata-rata dari kelompok tersebut. Diketahui nilai standar deviasi ROE lebih besar dari nilai standar deviasi CR. Semakin besar nilai standar deviasi menunjukkan bahwa data sangat beragam/bervariasi. Sedangkan nilai standar deviasi pada harga saham sebesar 0,98681 .

Pengujian keabsahan data melalui uji asumsi klasik salah satunya yaitu uji normalitas. Uji ini bertujuan untuk menguji apakah dalam model regresi variabel dependen dan variabel independen memiliki distribusi normal. Model regresi yang baik adalah model regresi yang memiliki distribusi normal atau mendekati normal (Rochaety et al., 2019). Hasil penelitian dengan data asli diperoleh data tidak normal, ada beberapa cara mengubah model regresi menjadi normal. Menurut Syafrizal et. all dalam Rochaety et al., (2019) yaitu melakukan transformasi data, misalnya mengubah data menjadi bentuk logaritma (Log) atau natural (Ln), menambah jumlah data, menghilangkan data yang dianggap sebagai penyebab tidak normalnya data (outlier), atau dengan menerima data apa adanya. Pada hasil penelitian data tidak berdistribusi normal, maka cara yang dilakukan dengan mencari data yang terkena outlier. 
Outlier yang digunakan dengan cara casewise (Sujarweni, 2015). Namun dari hasil penelitian setelah outlier dengan uji Kolmogrov Smirnov masih tidak berdistribusi normal dengan nilai signifikan $0,000<0,05$. Maka diperlukan transformasi yang mungkin membantu menormalkan data (Rochaety et al., 2019). Transformasi data merupakan cara mengubah data asli ke dalam bentuk lain dengan tujuan untuk memperbaiki distribusi data (Sarwono, 2018).

Hasil penelitian setelah transformasi data diperoleh nilai signifikan $0,066>0,05$ artinya data berdistribusi normal. Hasil uji normalitas dari penelitian ini menunjukkan hasil sebagai berikut ini:

Tabel 2.

Hasil Uji Normalitas

\begin{tabular}{lr}
\hline & Unstandardized Residual \\
\hline $\mathrm{N}$ & 53 \\
Asymp. Sig. (2-tailed) & 0.066 \\
\hline Sumber: Data diolah peneliti, 2020 & \\
Uji multikolinearitas menunjukan nilai Variance Inflation Factor (VIF) & \\
ROE dan CR. & \\
Nilai VIF pada ROE dan CR sebesar $1,062<10$ artinya VIF lebih kecil \\
kolerasi atau tidak terjadi multikolinearitas. Berikut ini merupakan hasil uji \\
multikolinearitas :
\end{tabular}


Tabel 3.

Hasil Uji Multikolinearitas

\begin{tabular}{|c|c|c|}
\hline \multicolumn{3}{|c|}{ Collinearity Statistics } \\
\hline Model & Tolerance & VIF \\
\hline \multicolumn{3}{|l|}{ (Constant) } \\
\hline ROE & 0.942 & 1.062 \\
\hline $\mathrm{CR}$ & 0.942 & 1.062 \\
\hline
\end{tabular}

Sumber: Data diolah peneliti, 2020

Uji heteroskedastisitas untuk mengetahui apakah pada suatu model regresi terdapat ketidaksamaan variance dari residual satu pengamatan ke pengamatan yang lain. Konsukuensinya apabila terdapat heteroskedastisitas dalam model regresi maka penaksir yang diperoleh tidak efisien, baik dalam sampel kecil maupun besar (Rochaety et al., 2019). Langkah yang dapat diambil untuk memprediksi ada tidaknya heteroskedastisitas dalam penelitian ini yaitu Uji Glejser. Hasil menunjukkan bahwa masing-masing variabel independen yaitu ROE dengan nilai signifikansi sebesar $0,170>0,05$ dan $\mathrm{CR}$ dengan nilai signifikansi sebesar 0,176 > 0,05. Sehingga dapat disimpulkan bahwa dalam model regresi tidak terdapat heteroskedastisitas. Berikut ini merupakan hasil uji heteroskedastisitas :

Tabel 4.

Hasil Uji Heteroskedastisitas

\begin{tabular}{lll}
\hline & Model & Sig \\
& \\
\hline ROE & & 0.170 \\
CR & & 0.176 \\
\hline
\end{tabular}

Sumber: Data diolah peneliti, 2020

Uji autokolerasi adalah untuk menguji apakah dalam model regresi linier ada kolerasi antara kesalahan pada periode $\mathrm{t}$ (sekarang) dan periode $\mathrm{t}-1$ 
(sebelumnya) (Rochaety et al., 2019). Hasil menunjukkan bahwa pengujian autokolerasi dapat diketahui nilai D-W sebesar 2,037. Hasil nilai D-W akan dibandingkan dengan nilai tabel $\mathrm{D}-\mathrm{W}$ signifikan $5 \%$ atau 0,05 dengan $(\mathrm{n}=53)$ dan jumlah variabel independen $(\mathrm{k}=2)$. Dengan melihat tabel $\mathrm{D}-\mathrm{W}$ maka didapat nilai $\mathrm{dL}=1,4797$ dan $\mathrm{dU}=1,6359$. Sehingga dapat dijabarkan $\mathrm{dU} 1,6359<2,037<$ 2,3641 (4- dU). Maka dapat disimpulkan bahwa nilai D-W sebesar 2,037 berada diantara batas atas atau upper bound (dU) dan (4- dU). Artinya dalam model regresi pada penelitian ni tidak terdapat autokolerasi.

Tabel 5.

Hasil Uji Autokolerasi

Model Summary ${ }^{b}$

Durbin-Watson

2.037

Sumber: Data diolah peneliti, 2020

Tabel 6.

Hasil Uji Regresi Linear Berganda

\begin{tabular}{|c|c|c|c|c|}
\hline \multirow[t]{2}{*}{ Model } & \multicolumn{2}{|c|}{$\begin{array}{l}\text { Unstandardized } \\
\text { Coefficients }\end{array}$} & \multirow[t]{2}{*}{$\mathbf{t}$} & \multirow[t]{2}{*}{ Sig. } \\
\hline & B & Std. Error & & \\
\hline (Constant) & 6.057 & 1.044 & 5.801 & 0.000 \\
\hline ROE & 0.639 & 0.158 & 4.037 & 0.000 \\
\hline $\mathrm{CR}$ & -0.274 & 0.175 & -1.561 & 0.125 \\
\hline
\end{tabular}

Berdasarkan hasil pengolahan data tabel 6 , diperoleh hasil persamaan analisis regresi linier berganda sebagai berikut :

Harga Saham $(Y)=6,057+0,639 \mathrm{ROE}-0,274 \mathrm{CR}$. 
Hasil persamaan analisis regresi linier berganda di atas diperoleh nilai konstanta sebesar 6,057 maka nilai konstanta positif, sehingga variabel harga saham (Y) dipengaruhi oleh kedua variabel independen yaitu ROE dan CR. Dalam persamaan regresi diatas, konstanta adalah sebesar 6,057 hal ini berarti jika tidak ada perubahan variabel $\mathrm{X}_{1}$ (Return On Equity), dan $\mathrm{X}_{2}$ (Current Ratio) yang mempengaruhi maka harga saham pada perusahaan subsektor property dan real estate sebesar 6,057. Koefisien regresi untuk variabel $\mathrm{X}_{1}$ yaitu Return On Equity (ROE) bernilai positif. Artinya adanya hubungan searah antara ROE $\left(\mathrm{X}_{1}\right)$ dengan Harga Saham (Y).

Koefisien regresi variabel $\mathrm{X}_{1}$ sebesar 0,639 artinya setiap pertambahan ROE sebesar satu satuan akan menyebabkan kenaikan harga saham sebesar 0,639 dengan asumsi bahwa variabel lain konstan atau sama dengan nol. Koefisien regresi untuk variabel $\mathrm{X}_{2}$ yaitu Current Ratio (CR) bernilai negatif. Artinya adanya hubungan tidak searah antara CR $\left(\mathrm{X}_{2}\right)$ dengan Harga Saham (Y). Koefisien regresi variabel $\mathrm{X}_{2}$ sebesar 0,274 artinya setiap pertambahan CR sebesar satu satuan akan menyebabkan penurunan harga saham sebesar 0,274 dengan asumsi bahwa variabel lain konstan atau sama dengan nol.

Berdasarkan tabel 6 dapat diketahui nilai $t_{\text {hitung }}$ pada setiap variabel. Untuk membuat kesimpulan menerima atau menolak $\mathrm{H}_{0}$ terlebih dahulu menentukan nilai dari $t_{\text {tabel }}$ yang akan digunakan. Peneliti menggunakan tingkat signifikansi 5\% dan uji t dilakukan dengan uji dua sisi (two tailed). Diperoleh bahwa $t_{\text {tabel }}=(0,025 ; 53-2-1)=(0,025 ; 50)=2,008$. 
Nilai $t_{\text {hitung }}$ ROE sebesar 4,037. Jika dibandingkan dengan nilai $t_{\text {tabel }}$ yaitu sebesar 2,008. Sehingga nilai $t_{\text {hitung }} 4,037>$ nilai $t_{\text {tabel }} 2,008$ atau nilai signifikansi sebesar $0,000<0,05$. Sehingga dapat disimpulkan Ho ditolak dan $\mathrm{Ha}_{1}$ diterima. Dengan demikian hipotesis menyatakan terdapat pengaruh secara signifikan antara return on equity terhadap harga saham pada perusahaan subsektor property dan real estate yang terdaftar di BEI.

Nilai $t_{\text {hitung }}$ CR sebesar -1,561. Jika dibandingkan dengan nilai $t_{\text {hitung }}$ yaitu sebesar 2,008. Sehingga nilai $t_{\text {hitung }}-1,561<$ nilai $t_{\text {tabel }} 2,008$ atau nilai signifikansi sebesar 0,125 >0,05. Sehingga dapat disimpulkan Ho diterima dan $\mathrm{Ha}_{1}$ ditolak. Dengan demikian, hipotesis menyatakan tidak terdapat pengaruh secara signifikan antara current ratio terhadap harga saham pada perusahaan subsektor property dan real estate yang terdaftar di BEI periode 2015-2019.

Pengujian hipotesis secara simultan yaitu dengan Uji F adalah pengujian signifikansi persamaan yang digunakan untuk mengetahui seberapa besar pengaruh variabel bebas secara bersamaan atau simultan terhadap variabel terikat. Penentuan hasil pengujian dapat dilakukan dengan membandingkan nilai $F_{\text {hitung }}$ dengan nilai $F_{\text {tabel }}$ serta dapat dilihat dari nilai signifikansinya.

Tabel 7.

Hasil Hipotesis Simultan

\begin{tabular}{lrrr}
\hline Model & F & \multicolumn{2}{c}{ Sig. } \\
\hline 1 & Regression & 11.559 & $.000^{\mathrm{b}}$ \\
\hline Sumber: Data diolah peneliti, 2020 & & &
\end{tabular}


Berdasarkan hasil uji f diperoleh nilai $F_{\text {hitung }}$ sebesar 11,559 untuk membuat kesimpulan diterima atau ditolaknya $H_{0}$. Ditentukan nilai $F_{\text {tabel }}$ dalam penelitian ini dengan tingkat signifikansi $5 \%$ maka $F_{\text {tabel }}=(0,05 ; 2 ; 50)=3,18$. Hasil uji f diperoleh nilai $F_{\text {hitung }}$ dengan nilai $F_{\text {tabel }}$ sehingga diperoleh nilai $11,559>3,18$ artinya nilai $F_{\text {hitung }}$ lebih besar dari nilai $F_{\text {tabel }}$. Nilai signifikansi senilai 0,000 lebih kecil dari 0,05 artinya terdapat pengaruh secara signifikan, sehingga $\mathrm{H}_{0}$ ditolak dan $\mathrm{Ha}_{1}$ diterima. Dengan demikian, hipotesis menyatakan terdapat pengaruh signifikan antara return on equity dan current ratio secara simultan terhadap harga saham.

Analisis koefisien determinasi $\left(\mathrm{R}^{2}\right)$ digunakan untuk mengetahui persentase perubahan variabel terikat $(\mathrm{Y})$ yang disebabkan oleh variabel bebas (X). Jika $\mathrm{R}^{2}$ semakin besar, maka persentase perubahan variabel terikat yang disebabkan oleh variabel bebas semakin tinggi. Jika $\mathrm{R}^{2}$ semakin kecil, maka persentase perubahan variabel terikat yang disebabkan oleh variabel bebas semakin rendah (Sujarweni 2015). Untuk mengukur koefisien determinasi dengan menggunakan angka R Square pada tabel Model Summary (Rochaety et al., 2019). Berikut ini merupakan hasil koefisien determinasi :

Tabel 8.

Hasil Uji Determinasi

\begin{tabular}{|c|c|c|c|c|}
\hline \multicolumn{5}{|c|}{ Model Summary ${ }^{b}$} \\
\hline Model & $\mathbf{R}$ & R Square & $\begin{array}{c}\text { Adjusted R } \\
\text { Square }\end{array}$ & $\begin{array}{l}\text { Std. Error of } \\
\text { the Estimate }\end{array}$ \\
\hline 1 & $.562^{\mathrm{a}}$ & .316 & .289 & .83219 \\
\hline
\end{tabular}


Hasil pengujian koefisien determinasi 0,316 atau sama dengan $31,6 \%$. Hal ini menunjukan bahwa besarnya pengaruh Return On Equity (ROE) dan Current Ratio (CR) sebesar 31,6\% terhadap harga saham. Sedangkan sisanya $68,4 \%(100 \%-31,6 \%)$ dipengaruhi oleh variabel yang tidak diteliti dalam penelitian ini atau variabel penggangu.

Pengaruh Return On Equity (ROE) terhadap harga saham. Hasil analisis data menunjukkan terdapat pengaruh secara signifikan antara return on equity terhadap harga saham pada perusahaan subsektor property dan real estate yang terdaftar di BEI periode 2015-2019. Dalam teorinya apabila hasil penelitian menunjukan adanya pengaruh secara signifikan antara return on equity terhadap harga saham. Apabila nilai ROE semakin tinggi berarti semakin baik kinerja perusahaan dalam mengelola modalnya untuk menghasilkan keuntungan bagi pemegang saham. Nilai ROE sendiri tidak memiliki batasan, karena ROE merupakan kemampuan mendapatkan laba, jadi tidak memiliki batasan.

Dengan adanya peningkatan laba bersih maka nilai ROE akan meningkat pula sehingga para investor tertarik untuk membeli saham tersebut yang akhirnya harga saham perusahaan tersebut mengalami kenaikan (Imelda et al., 2018). Oleh karena itu, dalam berinvestasi para investor perlu mempertimbangkan Return On Equity (ROE) sebagai salah satu pertimbangan dalam mengambil keputusan dalam berinvestasi, karena dari hasil penelitian ROE mempengaruhi harga saham. Jika perusahaan dapat memperoleh nilai ROE yang meningkat setiap periodenya, maka akan membuka kemungkinan datangnya investor-investor baru yang ingin 
menanamkan modal mereka ke perusahaan subsektor property dan real estate yang dapat meningkatkan harga pasar saham perusahaan tersebut.

Hasil penelitian ini sejalan dengan penelitian terdahulu yang dilakukan Alfrida Rianisari, Husnah , dan Cici Rianty K.Bidin, (2018) menyatakan bahwa, ROE berpengaruh positif dan signifikan terhadap harga saham. Hal yang sama juga dikatakan Imelda,Agus Satrya Wibowo, dan Muhammad Ichsan Diarsyad, (2018) menyatakan bahwa, return on equity mempunyai pengaruh signifikan terhadap harga saham. Sedangkan hal berbeda dikatakan oleh Mira Munira, Endang Etty Merawati, dan Shinta Budi Astuti, (2018) menyatakan bahwa, ROE secara parsial tidak memiliki pengaruh yang berarti terhadap harga saham.

Pengaruh Current Ratio (CR) terhadap harga saham. Hasil analisis data menunjukkan tidak terdapat pengaruh secara signifikan antara current ratio terhadap harga saham pada perusahaan subsektor property dan real estate yang terdaftar di BEI periode 2015-2019. Dalam teori apabila tidak terdapat pengaruh secara signifikan antara current ratio terhadap harga saham. Current ratio merupakan perbandingan antara jumlah aktiva lancar dengan jumlah hutang lancar.

Hal tersebut menunjukkan apabila perusahaan memiliki nilai current ratio yang tinggi maka bisa dikatakan perusahaan dalam jangka waktu pendek memiliki jaminan aset lancar untuk memenuhi kewajiban lancar yang sewaktuwaktu jatuh tempo. Namun, jika perusahaan mempunyai rasio lancar yang tinggi, belum tentu perusahaan tersebut dikatakan baik karena, dapat saja terjadi kurang 
efektifnya manajemen kas, adanya piutang usaha dalam aktiva lancar perusahaan dan adanya persediaan (Hery, 2016). Adanya persediaan yang tinggi artinya perusahaan juga harus melakukan usaha untuk menjual barang persediaannya dan perusahaan juga harus menunggu waktu jatuh tempo piutang supaya piutang dibayar dan adanya risiko yang berhutang tidak membayar kewajibannya (Filbert \& Prasetya, 2017).

Hal ini yang menjadi salah satu keterbatasan dari current ratio. Oleh karena itu, aktiva lancar yang tinggi tidak menjamin perusahaan dapat membayar kewajiban jangka pendek perusahaan yang segera jatuh tempo. Disimpulkan rasio lancar yang tinggi atau semakin likuid perusahaan tersebut, belum tentu berdampak positif pada harga saham. Jadi investor tidak memasukkan current ratio sebagai bahan pertimbangkan dalam melakukan investasi. Faktor lain adanya beberapa keterbatasan current ratio yaitu menurut Bernstein dan Wild dalam Rusli et al., (2011) mengatakan bahwa current ratio sebagai pengukur likuiditas memiliki keterbatasan.

Likuiditas digambarkan sebagai kemampuan untuk memenuhi arus kas keluar di masa depan dengan arus kas masuk yang cukup. Current ratio merupakan suatu ukuran yang statis (tetap) yang mengukur sumber daya yang tersedia pada suatu waktu tertentu untuk memenuhi kewajiban lancar. Sumber daya yang tersedia saat ini tidak cukup untuk merepresentasikan arus kas masuk di masa depan. Berdasarkan penelitian tersebut, dapat diartikan bahwa current ratio tidak dapat digunakan sebagai dasar untuk menentukan besar kecilnya nilai 
dari harga saham perusahaan property dan real estate. Hasil penelitian ini konsisten dengan penelitian terdahulu yang dilakukan oleh Efrizon, (2017). Menyatakan bahwa current ratio tidak mempunyai pengaruh yang signifikan terhadap harga saham. Hal sama juga dinyatakan oleh Cendy Andrie Pratama dkk (2019) menurut penelitian yang mereka lakukan bahwa current ratio terhadap harga saham tidak memiliki pengaruh secara signifikan. Tetapi berbeda dengan hasil penelitian oleh Ilmiyatus Sajiyah, (2016) menyatakan Current ratio (CR) secara parsial berpengaruh signifikan terhadap harga saham.

Pengaruh Return On Equity (ROE) dan Current Ratio (CR) secara simultan terhadap harga saham. Hasil analisis data menunjukkan terdapat pengaruh signifikan antara return on equity dan current ratio secara simultan terhadap harga saham. Nilai koefisien determinasi sebesar 0,316 atau sama dengan $31,6 \%$. Hal ini menunjukan bahwa besarnya pengaruh yang ditimbulkan dari return on equity dan current ratio. terhadap harga saham sebesar 31,6\% terhadap harga saham. Sedangkan sisanya 68,4\% dipengaruhi oleh variabel yang tidak diteliti dalam penelitian ini atau variabel penggangu.

Dalam teorinya apabila hasil penelitian menyatakan bahwa kemampuan return on equity dan current ratio berpengaruh sebesar $31,6 \%$ terhadap harga saham. Maka hal ini mengindikasikan adanya faktor lain yang mempengaruhi variabel independen di dalam penelitian ini. Terdapat berbagai faktor yaitu faktor internal dan faktor eksternal yang tidak diteliti yang mempengaruhi perubahan harga saham. Pengaruh faktor internal meliputi beberapa kondisi dan situasi yang 
menentukan suatu usaha saham itu mengalami fluktuasi yaitu, kondisi mikro dan makro ekonomi, peraturan perusahaan dalam memutuskan untuk melakukan ekspansi (perluasan usaha), peralihan direksi secara tiba-tiba, adanya direksi atau komisaris perusahaan yang pernah terlibat pidana dan kasusnya telah masuk ke pengadilan, kinerja perusahaan yang selalu mengalami penurunan dalam setiap waktunya, risiko sistematis dan dampak adanya psikologi pasar yang ternyata memberikan efek dalam menekan kondisi teknikal jual beli saham (Irham Fahmi, 2013).

Faktor eksternal, yaitu hal-hal yang terjadi diluar perusahaan antara lain kenaikan tingkat suku bunga yang mengakibatkan ketidakpastian pasar, pergerakan saham, terjadinya inflasi yang mengakibatkan ketidakpastian daya beli masyarakat, keadaan keamanan suatu negara, perekonomian negara lain, kebijakan pemerintah dan kondisi sosial politik.

\section{SIMPULAN DAN SARAN}

Berdasarkan analisis hasil penelitian menunjukkan terdapat pengaruh secara signifikan antara return on equity terhadap harga saham. Akan tetapi tidak terdapat pengaruh secara signifikan antara current ratio terhadap harga saham pada perusahaan subsektor property dan real estate yang terdaftar di BEI periode 2015-2019. Secara simultan return on equity dan current ratio terhadap harga saham memiliki pengaruh signifikan sebesar $31,6 \%$, sedangkan sisanya $68,4 \%$ dipengaruhi oleh variabel yang tidak diteliti dalam penelitian ini atau variabel penggangu. 
Saran yang dapat diberikan bagi investor untuk memperhatikan return on equity yang terdapat dalam laporan keuangan perusahaan dalam berinvestasi dengan harga saham karena hasil penelitian menyatakan adanya pengaruh ROE terhadap harga saham. Bagi perusahaan, disarankan agar lebih meningkatkan nilai return on equity perusahaan karena dengan meningkatkan nilai return on equity maka harga saham juga akan meningkat. Jika harga saham naik maka akan menarik banyak investor untuk menanamkan modal di perusahaan. Bagi peneliti selanjutnya disaran untuk menambah jumlah data dengan memperpanjang periode pengamatan atau dengan menambahkan variabel independen lainnya yang belum digunakan dalam penelitian ini.

\section{REFERENSI}

Amanah, R., Atmanto, D., \& Azizah, D. F. 2014. Pengaruh Rasio Likuiditas Dan Rasio Profitabilitas Terhadap Harga Saham (Studi pada Perusahaan Indeks LQ45 Periode 2008-2012). Jurnal Administrasi Bisnis, 12(1), 1-10.

Efrizon, J. A., Andalas, P. U., Andalas, J. U., Manis, L., \& Padang, K. 2017. Pengaruh Rasio Keuangan Terhadap Harga Saham Perusahaan Otomotif Periode 2013-2017.2(1).250-260.

Fahmi, Irham. 2013. Analisis Laporan Keuangan. Bandung: Alfabeta.

Filbert, R., \& Prasetya, W. 2017. Investasi Saham Ala Fundamentalis Dunia. Jakarta: PT Elex Media Komputindo.

Hery. 2016. Analisis Laporan Keuangan. Jakarta: PT Grasindo, Anggota IKAPI.

Imelda, Wibowo, A. S., \& Diarsyad, M. I. 2018. Pengaruh Current Ratio, Cash Ratio , Return on Equity Dan Return on Aseet Terhadap Harga. September, 12(1). 0-25.

Kasmir. 2012. Analisis Laporan Keuangan. Jakarta: Raja Grafindo.

Manoppo, V. C. O., Tewal, B., \& Jan, A. B. H. 2017. Pengaruh Current Ratio, Der, Roa Dan Npm Terhadap Harga Saham Pada Perusahaan Food and 
Beverages Yang Terdaftar Di Bei (Periode 2013-2015). Jurnal Riset Ekonomi, Manajemen, Bisnis Dan Akuntansi, 5(2), 1813-1822.

Munira, M., Merawati, E. E., \& Astuti, S. B. 2018. PENGARUH ROE DAN DER TERHADAP HARGA SAHAM PERUSAHAAN KERTAS DI BURSA EFEK INDONESIA. 4(3), 191-205.

Pratama, C. A., Devi Farah Azizah, \& Nurlaily, F. 2019. Pengaruh Return On Equity (ROE), Earning Per Share (EPS), Current Ratio (CR) dan Debt to Equity Ratio (DER) Terhadap Harga Saham. Jurnal Administrasi Bisnis, 66(1), 10-17.

Rahmadewi, P. W., \& Abundanti, N. 2018. PENGARUH EPS , PER , CR , DAN ROE TERHADAP HARGA SAHAM DI BURSA EFEK INDONESIA. 7(4), 2106-2133.

Rianisari, A., Husnah, \& K.Bidin, C. R. 2018. Pengaruh Likuiditas, Leverage, Dan Profitabilitas Terhadap Harga Saham Industri Makanan Dan Minuman Di Bei. JURNAL ILMU MANAJEMEN UNIVERSITAS TADULAKO, 4(2). 113-120.

Rochaety, E., Tresnati, R., \& Latief, A. M. 2019. Metodologi Penelitian Dengan Aplikasi SPSS Edisi 2. Jakarta: Mitra Wacana Media.

Rusli, L., En, T. K., \& Meythi. 2011. Pengaruh Likuiditas dan Profitabilitas Terhadap Harga Saham Perusahaan Manufaktur yang Terdaftar di Bursa Efek Indonesia. 10(2).1-20.

Sajiyah, I. (2016). Pengaruh Current Ratio, Debt To Equity Ratio Dan Return On Investment Terhadap Harga Saham Perusahaan Food \& Baverages Sekolah Tinggi Ilmu Ekonomi Indonesia Malang Pendahuluan. Akademika, 14(1). 19.

Sarwono, J. 2018. STATISTIK UNTUK RISET SKRIPSI (E. Kurnia (ed.)). Yogyakarta: ANDI.

Sudana, I. M. (2011). Manajemen Keuangan Perusahaan Teori \& Praktik. Jakarta: Erlangga.

Sujarweni, V. W. 2015. Metodologi Penelitian Bisnis \& Ekonomi. Yogyakarta: PUSTAKABARUPRESS. 